\title{
Esboços autoficcionais no teatro brasileiro: a escrita do eu andradino
}

\section{Autofictional schema in the Brazilian theater: Jorge Andrade's self-writing}

Carlos Gontijo Rosa ${ }^{1}$ 


\section{Resumo}

Este texto levanta algumas questões que nos instigam a ler teoria e textos de Jorge Andrade para além do seu lugar reconhecido e confortável: Por que retomar as memórias de Jorge Andrade em seus textos? É possível ler a obra de Jorge Andrade através da teoria da autoficção? É produtivo estabelecer pontos de comparação entre a narrativa e a dramaturgia? Neste texto, busca-se entender o uso da memória e da vida pessoal como fonte de imaginário poético para construção dos textos e, no caso de Jorge Andrade, a influência do ingresso na família da esposa, uma tradicional família quatrocentona como recurso poético autoficcional de composição do ciclo Marta, a árvore e o relógio (1951-1970).

Palavras-chave: Jorge Andrade; autoficção; memória
Abstract

This paper raises some questions that makes us read theory and Jorge Andrade's texts beyond theirs stablished situation: Why resume Andrade's memories to read his texts? Is it possible to read Andrade's oeuvre through autofiction theory? Is it productive to stablish comparison points between narrative and dramatic genres? On this paper we seek to understand the author's memory and personal life as source of poetic imagination to write his texts. Specifically, on Andrade's case, his marriage with a traditional family's daughter as autofictional poetical resource to compare with his work Marta, a árvore e o relógio (Martha, the tree and the clock, 1951-1970).

Keywords: Jorge Andrade; autofiction; memory

E-ISSN: 2358.6958

${ }_{1}^{1}$ Pós-doutorando em Literatura Brasileira pela USP. Doutor em Literatura Portuguesa pela mesma Universidade. Mestre em Teoria e História Literária e Bacharel em Artes Cênicas pela UNICAMP. carlosgontijo@gmail.com 
Tratar da obra de Jorge Andrade e da reverberação, talvez do retrato que pinta do momento histórico vivenciado pelo autor em sua infância, é lugar-comum dos estudos da literatura dramática brasileira. Esta informação, mais do que um achado historiográfico, é reiterada a cada aparição pública do autor, além de figurar em praticamente todos os textos que analisam suas obras. Por que, então, tornar a este lugar, já vastamente explorado e conhecido da crítica?

Além disso, no final do século XX e neste início de século XXI, cresceu entre os ficcionistas e críticos literários a ideia da autoficção. Partida de um quadro em branco no esquema de um autor francês (Philippe Lejeune, O pacto autobiográfico, 1973), outro autor francês (Serge Doubrovsky, Fils, [1977] 2001) se sentiu instigado a propor uma literatura até então desconhecida: um texto ficcional calcado na experiência do eu empírico que escreve. A questão foi levantada, discutida e aprofundada por muitos franceses, desde então (como pode ser visto no livro organizado por Jovita Maria Gerheim Noronha, Ensaios sobre a autoficção, 2014). Por que inserir esta discussão - demasiadamente francesa para o calor dos trópicos - na leitura de um autor brasileiro?

Terceiro e também contundente tópico é que grande parte dessa teoria é desenvolvida sobre a figura do narrador do romance, cujo grifo no texto não se faz em vão. O teatro - não qualquer teatro, mas aquele escrito por Jorge Andrade e outros - prescinde da figura do narrador, justamente por dar espaço a situações "presentes" através da presença das personagens, que falam, agem e reagem. Assim, por que levantar uma teoria ligada à narrativa para a leitura de textos dramáticos?

Estas são questões que nos instigam a ler teoria e textos andradinos para além do seu lugar reconhecido e confortável. O retrato da crise cafeeira, a autoficção, a memória de Jorge Andrade; todos estes elementos, díspares e dissonantes entre si, ecoam no sentido máximo da literatura: incomodar - este entendido como "criar movimento". Adentremos, pois, neste inusitado (será?) diálogo para ver como saímos dele, instigados pelo pensamento de Leonardo Tarifeño (2017, p.50, grifo nosso):

Toda historia literaria, aun la más hermética, procede de un fondo autobiográfico; que ese origen sea o no verificable no es tan significativo como lo que el autor puede hacer con él.

Teremos por auxílio o texto de Bruno Lima (Eu: itinerário para a autoficção, 2015) como princípio motivador de nossa leitura, especialmente quando o jovem autor vê em Graciliano Ramos não um autoficcionista, mas uma estação do "itinerário" da literatura brasileira rumo à autoficção:

A presença das memórias do autor dentro da obra de ficção não é suficiente, entretanto, para descaracterizá-la, mas agora se acresce, de forma ainda ingênua, a experiência empírica do escritor num universo até então restrito à imaginação, à criação, enfim, à ficção (Lima, 2015, p.32).

Ainda ingênuo porque não delimitado crítica e teoricamente, Graciliano Ramos inserta seu universo individual na literatura, "com acabamento e rigor estéticos dignos da pena ramosiana" (Lima, 2015, p.34). Seu contemporâneo mais novo, Jorge 
Andrade, segue o mesmo caminho no seu teatro.

Entretanto, antes de falar do teatro andradino em sua vertente possivelmente autoficcional, convém voltar à referência a Graciliano Ramos e determo-nos brevemente no romance autobiográfico Labirinto, publicado por Jorge Andrade em 1978. As evocações mnemônicas disparadas pelos encontros, diálogos e sensações das situações narradas pelo autor remetem aos primeiros capítulos do autor paraibano em Infância. Ambos memorialísticos, a incorporação da ideia de "fluxo de pensamento", eivado de lacunas, reticências, interpolações de fatos díspares, enfim, de uma escrita em que "desde o início, reconhece-se a voz de um narrador [...] o leitor se vê diante desse tipo de sinalização antes de perceber, por exemplo, a relação existente entre o nome do personagem e o do autor" (Lejeune, 2014, p.70):

Defronte alargava-se um pátio, enorme também, e no fim do pátio cresciam árvores enorme, carregadas de pitombas. Alguém mudou as pitombas em laranjas. Não gostei da correção: laranjas, provavelmente já vistas, nada significavam. (Ramos, 2015, p.10). [...]. Acordei, reuni pedações de pessoas e de coisas, pedaços de mim mesmo que boiavam no passado confuso, articulei tudo, criei o meu pequeno mundo incongruente. (p.21) [...]. Desse antigo verão que me alterou a vida restam ligeiros traços apenas. E nem deles posso afirmar que efetivamente me recorde. O hábito me leva a criar um ambiente, imaginar fatos a que atribuo realidade. (Ramos, 2016, p. 27)

O olhar, agudo, examina-me constantemente, meio irônico. De repente, ele [Gilberto Freyre] se ergue, ágil para a sua idade, colocando a mão em meu ombro. $\mathrm{O}$ rosto, com qualquer coisa de judeu, ganha expressão maliciosa, perguntando: - Vamos à pitangada? É de minha invenção: pinga, licor de violetas e pitangas. Com as pitangas, vem o cheiro de fubá torrado, passando entre folhas de taioba. Alguma coisa no ambiente me faz lembrar as plantas à beira d'água. [...] A lembrança escondia-se, não em objetos, mas em sons: o borbulhar da água não vem somente do pátio mourisco, mas de bica distante levando água ao monjolo e à roda d'água, também cercados de plantas [...]. Na casa da memória, sons, formas, odores, plantas, bichos, marrecos, patos, borboletas, expressões ou sentimentos, permanecem na mesma gaveta. Passo das folhas de taioba para sons de roda d'água: ruonn, ruonnn; para batidas do monjolo socando milho: iiiponn, iiiponnnn; para a voz de minha avó-onça, fazendo farinha de milho.

- Onde será que se enfiou esse menino! (Andrade, 1978, P.81-82)

No que concerne às questões de convergência ou divergência em relação aos nomes do autor, narrador e protagonista, deter-nos-emos em outro momento. Neste texto, buscaremos tratar da utilização do material da vida do autor (e, portanto, intransferível como leitura da realidade) enquanto subsídio para a produção artístico-literária. Assim, retomando Labirinto, percebemos claramente uma autobiografia ficcionalizada, pois sua composição segue e remete à evocação das memórias e elaboração do pensamento de uma pessoa verossimilmente construídas com vistas à emulação de um ser vivente real:

O eu recente busca o eu remoto para reinventá-lo. O que resulta é um livro literário e autobiográfico. O passado não tem a solidez dos documentos. As dores, mais que os prazeres, estão na escrita e na vida narrada. O passado é uma densa bruma. O contador hesita, duvida, esquece-e-lembra, mas o romancista maduro e o artesão virtuoso mostram-se, fundem-se com o menino e se afastam dele. (Leitão, 2015, p.269) 
Enquanto fala de Ramos, Cláudio Leitão poderia perfeitamente estar descrevendo o labor de Jorge Andrade no seu romance autobiográfico, em que, simulacro de memória, o autor desenha e delineia com graça de artífice a reconstrução mnemônica dos fatos, suas lacunas, imprecisões e sensações ${ }^{2}$, tomando ponto de vista duplo, do menino que sente e do adulto que analisa e percebe as consequências do sofrimento pueril em si:

Escondo-me como estou agora. Mal respiro com a água até o nariz: parada sobre a ponte, a tia com minhas roupas nas mãos. Ela sabe onde estou. Demora-se torturando-me! Sinto sobre a ponte os anjos do Castelo de Sant'Angelo - se pudessem me proteger! - e penso no sofrimento dos prisioneiros do Castelo de Scarpia, que eles também não protegeram. (Andrade, 1978, p.56)

Ao conferir tratamento literário às suas autobiografias, ambos os autores esgarçam as fronteiras do gênero, já percebido no canônico Graciliano Ramos pelo não menos canônico Antonio Candido (2006, p.90): "Infância é autobiografia tratada literariamente; a sua técnica expositiva, a própria língua parece indicar o desejo de lhe dar consistência de ficção".

A "recriação do passado, respaldado por sua memória, por sua lembrança" (Lima, 2015, p.34), conferida ao texto de Jorge Andrade, à exemplo do que também faz Ramos, remete Labirinto a um estatuto que expande a autobiografia à categoria literária.

Entretanto, a escrita autoficcional separa-se da ideia de autobiografia ao nublar o pacto autobiográfico defendido por Lejeune, no qual o autor se compromete à aproximação da verdade. ${ }^{3}$ Portanto, não podemos dizer que Infância e Labirinto se inscrevam na autoficção, mesmo que como gênese do gênero - seu texto (estilo, objeto, narrativa, tema...) é muito explicitamente colado à vida do autor empírico. Por outro lado, temos, dos mesmos autores, textos como Vidas secas e A moratória, nos quais Ramos e Andrade, respectivamente, projetam sua experiência de vida (ou conhecimento de mundo) enquanto matéria-prima da elaboração artística.

Obra de grande alcance na literatura brasileira, Vidas secas é objeto de estudo nos mais diversos âmbitos do estudo de literatura. Ela

[...] narra a trajetória de uma família de retirantes que procura sobreviver às condições adversas impostas pelo meio natural, como a seca e a caatinga, e pela realidade social, como o latifúndio e o drama dos retirantes. (Sobral, 2016, p.102)

\footnotetext{
2 "Como observador, sem julgar e condenar, ele [Jorge Andrade] forja a própria ética. Essa ética o situa como inimigo da violência e das injustiças sociais. A compreensão quase nostálgica da aristocracia, que perdeu seus privilégios e à qual pertence, não o impede de reconhecê-la morta. 0 amor à liberdade, estruturado no empenho solidário com todos os movimentos contra as tiranias, o faz repelir as ditaduras, cujos fins justificariam os meios. 0 mergulho na História vale para sair do labirinto do presente" (Magaldi, 1978, p.11). Introdução Labirinto.

${ }^{3}$ Diana Klinger resume a discussão aventada acerca da flexibilidade das preceptivas autobiográficas discutidas por Lejeune e Costa Lima: "Se para Lejeune, a autobiografia é uma questão de 'tudo ou nada' (Lejeune, 1975, p.25), para Costa Lima o estatuto da autobiografia é ambíguo. [...] Costa Lima conclui: 'não é mesmo por aquela impossibilidade de contrato estável com o leitor de que o autobiográfico ora se inclina para a história, ora para o ficcional?' (1986, p.307, itálico nosso). $O$ argumento de Costa Lima tem, a respeito de Lejeune, a vantagem de 'abrandar' a noção de pacto. Uma vez que o estatuto da autobiografia é ambíguo, nenhum pacto definitivo pode ser estabelecido. Porém, ele estabelece a equivalência entre os termos 'literatura' e 'fição', de maneira que não somente exclui a autobiografia da literatura [...] mas também não inclui os casos híbridos" (Klinger, 2007, p.43). Escritas de si escritas do outro.
} 
Rigorosamente, não é necessário saber nada sobre o autor para se poder apreciar Vidas secas. Mais que isso, ao se saber que o próprio Graciliano é nordestino e viajou pelo Nordeste com a família, quando criança, tampouco causa ao leitor mais do que a percepção de que este autor escreve sobre um ambiente conhecido. Só a partir do reconhecimento de seus procedimentos de escrita, podemos associar a vivência de Graciliano à sua produção literária:

Adepto da experiência como condição de escrita, Graciliano Ramos emprestará a seus personagens suas práticas e visões de mundo. (Lima, 2015, p.34)

Ou seja, se faz necessário reconhecer todo o espaço biográfico ${ }^{4}$ do autor-criador ${ }^{5}$ Graciliano Ramos para reconhecê-lo em seus textos, como por exemplo a carta enviada por Ramos a João Condé, cujo excerto citado foi publicado no jornal O Cruzeiro, em 1944:

[...] no começo de 1937 utilizei num conto a lembrança de um cachorro sacrificado na Maniçoba, interior de Pernambuco, há muitos anos. Transformei o velho Pedro Ferro, meu avô, no vaqueiro Fabiano; minha avó tomou a figura de sinhá Vitória, meus tios pequenos, machos e fêmeas, reduziram-se a dois meninos. (apud Sant'Anna, 1989, p.168)

Tendo consciência, ainda, da impossibilidade da autoficção nos textos ramosianos, podemos entender esta referência à realidade factualmente vivida enquanto recurso poético de construção da ficção a eles inerente. Isso porque, virtualmente, nenhuma outra individualidade seria capaz de, ainda que experienciando as mesmas experiências, extrair delas a mesma mundividência: ${ }^{6}$

Se a primeira pessoa não figura em Vidas secas, como ocorre em seus outros romances, ela é compensada, em certa medida, pelas características do próprio autor emprestadas a Fabiano, de acordo com declaração de Graciliano . (Lima, 2015, p.31)

O espaço biográfico abarca a obra de Graciliano Ramos e nos permite perceber traços autobiográficos em seus escritos - aquilo a que estamos chamando de recursos autoficcionais de composição. Este espaço biográfico, conquistado e descoberto através de entrevistas e outras obras, nos permite, enquanto leitores, uma aproximação à figura empírica do escritor. Assim, é a partir da publicação de seus textos autobiográficos, entrevistas e outros meios de comunicação deste autor-criador que

\footnotetext{
${ }^{4}$ Mitidieri (2013, p.141) define o espaço biográfico como "intersecção que abriga nem tão somente a autobiografia, a biografia e narrativas circunvizinhas, mas também as formas (auto)biográficas precedentes à instituição desses gêneros e outras notações culturais de ordem similar ou mesmo estilizadas hibridizadas, matizadas por traços (auto)biográficos".

${ }^{5} \mathrm{O}$ conceito de "autor-criador" é aqui utilizado na acepção bakhtiniana do termo, em oposição ao autor empírico ou autor-pessoa. Faraco (2017, p.37) afirma que Bakhtin "distingue o autor-pessoa (isto é, o escritor; o artista) do autor-criador (isto é, a função estético-formal engendradora da obra). Este último é, para Bakhtin, um constituinte do objeto estético [...] o pivô que sustenta a unidade do todo esteticamente consumado".

${ }^{6}$ Estabelece-se, aqui, uma relação proximal entre a teoria autobiográfica e o conceito bakhtiniano do cronotopo. Bakhtin (2018, p.11) define o conceito de cronotopo como "a interligação essencial das relações de espaço e tempo como foram artisticamente assimiladas na literatura".

7 "Se fosse analfabeto, por exemplo, seria tal qual Fabiano..." (Lima, 2015, p.31 apud Senna, 1977, p.55).
} 
nos aproximamos de sua personalidade empírica para a compreendermos decalcada na literatura:

O leitor não tinha subsídios para, unicamente através do texto, detectar dados biográficos de Graciliano e não havia nenhum dado extratextual que despertasse a desconfiança do leitor de se tratar de um texto com premissas autobiográficas. (Lima, 2015, p.31)

Para a textualidade andradina, Labirinto tem a mesma função pois, enquanto romance assumidamente autobiográfico, revela passagens da vida do autor que podem ser distinguidas em situações dramáticas apresentadas em suas peças. ${ }^{8}$

Labirinto, entretanto, vai além, pois, no próprio texto, Jorge Andrade estabelece inúmeros paralelos entre a sua produção artística pregressa (Marta, a árvore e o relógio; Milagre na cela) e imagens de sua infância e adolescência:

Os cem cruzeiros oferecidos transformam Manoel e ele anima-se, alisando o caixão da caridade. Pressinto que os mortos de ontem e os de amanhã vão começar a me acompanhar. [...]. Já não é mais o rosto de Manoel que está em minha frente: são muitos que conheci na fazenda de meu pai, sentado sob cafeeiros, andando nos carreadores, em torno dos montes de milho, perto dos bateadores de arroz ou no eito das capinas. [...] Entre muitos, distingo o rosto do meu amigo Devair, com quem trabalho entregando sacas de café na colônia. [...]. Distingo o de Irânides, casando em Jaborandi e atravessando - noivo, noiva, padrinho (eu), convidados - as ruas numa nuvem de poeira. O de Carlinda, demônio desesperando casadas, atormentando solteiros, pondo em cada homem vontade de abandonar a filharada. Carlinda - ou Artuliana atormentando Joaquim? Joaquim - ou Devair que vivia agoniado por Carlinda, vendo-a dar para todos os homens da fazenda, menos para ele? (Andrade, 1978, p.109-110)

Entretanto, vale a pena sempre alertar que a leitura que se empreende aqui dista daquela leitura biográfica, tão em voga durante o século XIX. Ao definir "Quando não utilizar dados biográficos na análise literária", Frankel (2014, p.64) conclui que "a atribuição de vínculos biográficos ao material literário só deve ser feita como parte de um projeto de análise literária no qual essa atribuição efetivamente traga benefícios". Isto porque, ao analisar o romance O lobo da estepe, de Hermann Hesse (1927), o estudioso identifica a simplificação da leitura do romance, se aventada a via biográfica de interpretação. Embora apresente diversos traços autoficcionais, esta forma de análise suplantaria uma análise existencialista a partir do conceito heideggeriano de angústia, pois desvincularia o leitor de uma imersão e compartilhamento do sentimento do protagonista.

Frankel privilegia uma leitura existencialista em detrimento de outra, autoficcio-

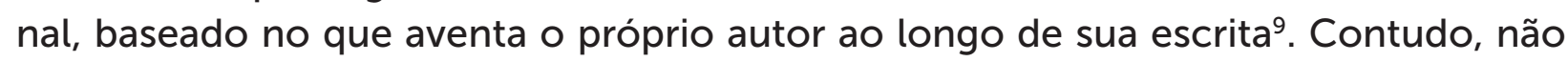

\footnotetext{
${ }^{8}$ Embora, como parte do jogo de gato e rato estabelecido entre leitor e autor, o próprio Jorge Andrade, em entrevista: "Se eu perguntar o que é autobiográfico no Labirinto, não terei uma resposta concreta. Há no meu livro situações que julgam 'realidade' e que são inteiramente de ficção. Talvez porque eu tenha procurado a ambivalência no julgamento. Esta dúvida ninguém pode esclarecer, a não ser eu mesmo. Quando leio o livro, confesso que eu também não sei mais o que é realidade ou ficção". (DT 7704, AMM/CCSP, s/d., f.16).

${ }^{9}$ Como epígrafe da Introdução do artigo, Frankel traz a citação do posfácio de Hesse (2011, p.238): "É claro que eu não posso nem pretendo dizer aos meus leitores como devem entender a minha história. Que cada um nele encontre aquilo que lhe possa ferir a corda íntima e o que lhe seja de alguma utilidade! Mas eu me sentiria contente se alguns desses leitores pudessem perceber que a história do Lobo da Estepe, embora retrate enfermidade e crise, não conduz à destruição e à morte, mas, ao contrário, à redenção".
} 
acreditamos nesta dicotomia, mas na complementaridade das análises - como, por sinal, o próprio autor faz na estrutura do artigo. Também Lejeune, em O pacto autobiográfico (bis), fala desta postura dogmática em relação aos elementos de análise da literatura - e não de forma elogiosa. Ambas as leituras estabelecidas por Frankel são francamente bem elaboradas, e ambas deveriam ser consideradas.

No nosso caso, portanto, levaremos em conta os espaços biográficos das figuras autorais, pois, como ainda afirma Lima (2015, p.32):

Esse comportamento memorialista que se apresenta no modernismo põe em xeque a tradição do romance como fingimento e causa um problema para o crítico. Com o deslocamento do fingimento para a memória afetiva, parece que não é mais possível considerar apenas o texto na leitura, pois signos extratextuais e a própria vida do autor assumem importância.

Retornando a Jorge Andrade, Labirinto, portanto, nos lança luz sobre procedimentos autoficcionais presentes na composição de suas peças teatrais do ciclo Marta, a árvore e o relógio, datadas principalmente das décadas de 1950 e 1960, mas também com muita presença em Milagre na cela, de 1977. As duas obras, entretanto, são tratadas de maneira muito variada no romance.

Milagre na cela foi lançada um ano antes de Labirinto. Como se pode perceber na dramaturgia andradina, existe um diálogo em toda a sua obra, entre as peças que a compõe. Assim é que, por exemplo, em A escada, escrita em 1961, já há uma indicação da escrita tanto de As confrarias (1969), quanto de O sumidouro (1970):

Izabel: A peça sobre Fernão Dias está parada há um ano. A que pretendia escrever sobre as confrarias de Ouro Preto, ficou apenas na intenção. Em vez de sofrer pelo passado, use-o para se realizar. Ele não está contido no presente de todo mundo? Pegue essa gente, barões ou não, e jogue no palco. É uma boa maneira de se libertar. (Andrade, 1970, p.392)

Pela proximidade do lançamento de Milagre na cela e Labirinto, entende-se que os períodos de composição dos textos é o mesmo. Assim, o romance autobiográfico expõe o caminho composicional da peça, corroborado em entrevista de 1976 (TR1823, CCSP). Francisco Iglésias, em texto crítico sobre o Labirinto, afirma que "seu valor está no que confessa e na forma pungente de expressão" (DT-7716, CCSP, p.1). E ainda ressalta que "em cada uma dessas figuras vai buscar o que são, o mundo em que viveram ou criaram. Busca ou encontra sobretudo a própria imagem, seu passado e os retratos de parentes e amigos" (DT-7716, CCSP, p.2).

Ao buscar uma aproximação aos recursos autoficcionais de composição, tiramos nosso olhar dos aspectos autobiográficos, como o caminho traçado para a escrita de Milagre na cela, e voltamo-nos para suas memórias e como elas refletem poeticamente em alguns textos de Marta, a árvore e o relógio. Ainda a fim de delimitar nosso olhar à autoficção como aspecto distinto da autobiografia, como discutido acima, não nos debruçaremos sobre as personagens Vicente apresentadas nas peças A escada, Rasto atrás e $O$ sumidouro, por se tratar, como já apresentado em diversos estudos, de personagem autobiográfica.

Assim ainda seguindo o rasto apresentado no espaço biográfico que define o 
autor-criador Jorge Andrade, em entrevista de 1976, respondendo a uma pergunta de Mariângela Alves de Lima, ele diz que:

É fácil verificar assim no meio das peças o momento em que o autor casa-se. Esse casamento, por exemplo, tem uma grande influência, porque ele se casa com uma moça realmente quatrocentona, quer dizer, a única quatrocentona legítima que eu conheço, descendente das dezesseis famílias da caravela MESMO, então vem todo um mundo que completava a família paulista para a visão do autor. Então vai se alargando, porque se ela é quatrocentona, e se ela faz parte, tem consciência de fazer parte desta família paulista, desta História paulista, essa consciência passa na convivência para o autor também. (TR-1823, CCSP, p.4)

O casamento de Jorge Andrade com Helena de Almeida Prado ocorre em 7 de dezembro de $1956 .{ }^{10}$ Após esta data, pertencentes ao ciclo, o autor escreve três peças que tratam diretamente do assunto: A escada (1961), Os ossos do barão (1962) e Senhora da Boca do Lixo (1963). Além destas, a complexa O sumidouro (1970) também levanta esta questão ao trazer à cena o próprio Fernão Dias.

Em $A$ escada, temos "pai e mãe como fantasmas vivos na cidade, vistos através dos olhos de seus [quatro] filhos. Estes efetuaram seu respectivo ajustamento à vida urbana, exceto na perplexidade, culpa e exasperação causados pela carga sentimental do passado que seus anacrônicos pais representam" (Morse, 1970, p.646). A apresentação de Richard Morse chama a atenção para os "anacrônicos pais" dos protagonistas de $A$ escada. São duas figuras que apresentam, esquematicamente, preconceitos e uma visão de mundo há muito ultrapassada:

Antenor (olha a cesta com desprezo): Neta de barão carregando cesta de verduras! Maria Clara: Neta de barão, mas sem empregada. (Andrade, 1970, p.346)

O anacronismo do pensamento dos velhos contrasta com os valores vigentes entre as demais personagens, que correspondem à época atual à representação ou seja, década de 1960. A liberdade conferida aos "pais anacrônicos" pelos filhos permite que seus preconceitos sejam expressos também socialmente, como quando encontram com o zelador do prédio, Juca, na escada.

Antenor: Como se chama o senhor?

Juca: José. José dos Santos.

Antenor: Será dos Santos, de Amparo?

Juca: Não sei, não senhor.

Antenor: Conheci uns Santos, de Amparo. Gente brava, mas muito boa. Houve até o caso de uma mãe que matou a filha.

Juca: Dos Santos, de Amparo?

Antenor: É! A moça estava vendo passar a procissão, debruçada na janela. A mãe morreu de vergonha do vigário. Ah! Não teve dúvida. Chegou em casa e deu um tiro na filha. Matou. Era gente de muito respeito. Debruçar em janela, nem mulher de vida fácil, o senhor não acha? (Andrade, 1970, p.347)

\footnotetext{
10 "Se foi em março, ao findar das chuvas, quase à entrada do outono que Fernão Dias entrou pelo sertão buscando esmeraldas e prata, na minha vida ele entrou de fato no mês de dezembro, exatamente no dia sete, na Capela da Universidade Católica, quando me casei com Helena. E entrou para nunca mais sair, já que meus filhos descendem de uma sua irmã" (Andrade, 1978, p.168-169).
} 
Esta cena é repetida, com pequenas alterações, nos três atos da peça, o que demonstra não apenas um comprometimento da capacidade mental dos velhos Antenor e Amélia, como também uma ideia fixa com a questão da tradição. Entretanto, esta ideia fixa dos velhos pais acaba influenciando nas relações dos demais parentes com o mundo que os rodeia. Tal reflexo pode ser percebido, em âmbitos diferentes, nas personagens Sérgio, Zilda e Francisco.

O segundo ato mostra, em relação ao casal de idosos, a sua mudança da casa da filha Helena Fausta para a casa de Vicente. No início do ato, em conversa com sua esposa Helena, Sérgio diz:

Sérgio: Todo mundo me deu notícia de seu pai na cidade. Vocês não deviam deixá-lo sair tanto.

[...]

Sérgio: Sabe que esteve muitas vezes na firma?

Helena: Quando?

Sérgio: Nos dias em que viajei.

Helena: Foi fazer o quê?

Sérgio: Conversar! Simplesmente, conversar! Perguntou sobre a ascendência de Deus e todo mundo. Num lugar onde trabalham descendentes de sírios, italianos, alemães, gaúchos e nortistas... você deve calcular o resultado.

Helena: É tão fácil compreender papai!

Sérgio: Para vocês. Acharam muita graça! E acabaram me apelidando de príncipe consorte! Que eu ouça, durante dez anos, as mesmas perguntas, aqui dentro de casa, vá lá. Mas ir ao meu trabalho e me ridicularizar, é o que não vou permitir.

Helena: É um velho! Será que ninguém compreende, meu Deus!

Sérgio: Isso enche.

Helena: Você é grosseiro.

Sérgio: Comecei do nada! Subi com muito esforço. Não vou admitir que essa mania besta de nobreza destrua tudo. Sou Albuquerque e Bragança, de Pernambuco, é verdade, mas não sou parente do Imperador e não sei e nem me interessa saber se meu tataravô tomou parte na Batalha dos Guararapes! Estou farto de repetir. (Andrade, 1970, p.358-359)

O conflito entre a tradição e a modernidade, nesta peça de Jorge Andrade, apresenta tons monocromáticos, colocando tais mundividências em campos opostos do conflito. O embate social, no ambiente de trabalho de Sérgio, reflete o passado da família, em que os pais, com o apoio do filho mais velho, Francisco, interferem na vida amorosa das irmãs Zilda e Lourdes, filhas de Maria Clara. Criadas sem a figura masculina, pai e tio se impõem como bastiões protetores das jovens moças, decidindo por elas com quem é melhor se relacionarem.

Com Zilda, a interferência que ocorre não é explícita, mas explicada por Omar no terceiro ato - "Omar (desesperado): Você não vê que seu avô estragou tudo?" (Andrade, 1970, p.384) - aquilo que já se pressupunha de diálogo em cenas anteriores, entre Zilda e sua irmã, Lourdes: "Lourdes: Há muitos dias que Omar desapareceu. (Andrade, 1970, p.381). No final da peça, entretanto, os dois se reconciliam e continuam o namoro.

Já com Lourdes, a irmã mais velha, a intervenção foi determinante para seu futuro, pois permanece solteira:

Zilda: Sabe? Você está precisando, mesmo, é de homem.

Lourdes: Vou mandar a família escolher um pra mim. 


\section{$[\ldots]$}

Zilda: Tenho pena de você. Lá fora a vida continua, tudo evolui, o homem chega à lua, e você aqui, sentada, com certeza pensando em alguém que seja digno de você. Qualquer casamento é bom, nem que seja pra desmanchar depois.

Lourdes: Você não sabe de nada.

Zilda: Sei, sim. Só porque permitiu que tio Francisco desmanchasse seu casamento, fica escondida nesta sala, como um cacto, jogando espinho pra todo lado. [...]

Zilda: [...] O resto da confraria mais intolerante, mora neste prédio... ainda expulsando gente por infâmia de mulato, ou de italiano. "Italianinho de brinco na orelha", lembra-se? (Andrade, 1970, p.380-381)

Francisco é a figura que busca a manutenção do status social da família. A personagem interfere na vida dos demais membros da família, como se pode ver na citação anterior, sobre um namoro de Lourdes. No terceiro ato, influenciado pela monomania do pai, busca a reafirmação do poder familiar a partir de uma possível herança que lhes deixaria donos de todo o Brás, região da cidade de São Paulo, mas que foi negada por vários juízes a que foi submetida.

Noêmia: Francisco! Você não vê que isso é loucura? Volte a si, meu velho! Há dois meses que lê esses papéis como um desesperado. (Andrade, 1970, p.381)

Já claramente manifesta no terceiro ato, a monomania de Francisco se apresenta na cena final do segundo ato, quando os irmãos mais novos propõem a internação dos pais em um Instituto, após o pai receber uma intimação judicial sobre seus "negócios" na cidade com os terrenos que não the pertencem. Francisco é terminantemente contra, abriga seus pais em seu apartamento, abandona o emprego e se dedica a reconquistar os terrenos do Brás.

Noêmia: Nós vivíamos tão bem, Francisco! Não precisamos do Brás.

Maria Clara: Francisco! É preciso pensar nos outros também. Você tem mulher e filho.

Helena: Saber que estão internados no Instituto não é nenhuma vergonha.

Francisco: Para nós, é. Que vão dizer os parentes, os amigos?

Maria Clara: Vergonha é abandonar emprego, esquecer da família... por o nosso orgulho acima de tudo. Basta o que papai fez a família dele passar, por causa dessa demanda. Não faça o mesmo com a sua, Francisco!

Francisco: O que é que tem a minha família?

Maria Clara: Seu filho foi reprovado e você nem toma conhecimento. Noêmia está sofrendo, e você agarrado a esses papéis que já deviam estar no lixo. (Andrade, 1970, p.388)

A questão nobiliárquica, em $A$ escada, tem caráter secundário e complementar à questão financeira envolvida nos terrenos do Brás, cuja obtenção recolocaria a família socialmente, na visão conturbada de Francisco, herdeira da monomania paterna. Portanto, em $A$ escada, já se percebe uma representação caduca dos valores passados como incabíveis na realidade contemporânea das personagens, representados pelos "pais anacrônicos", mas também por Francisco, uma personagem tragada por esta fixação nobiliárquica-financeira.

Um olhar sobre os quatrocentões paulistas e sua decadência já se esboçava, de forma esquemática, na briga entre o casal Leila e Luís, em O telescópio (1951). A 
personagem masculina, claramente destoante das demais personagens - pertencentes à família de Leila, em cuja casa na fazenda se dá a ação -, é acusada por Leila de constrangê-la na capital:

Leila: Ah! É? Lembro-me muito bem: "Luís! Você também pertence à família de quatrocentos anos, não é? Descende de quem, mesmo? Ah! A marquesa! A baronesa! Sua árvore genealógica é bem definida, Luís, uma das mais tradicionais! Nela estão contidas as dezesseis famílias da caravela de Martim Afonso de Souza! E você, Leila, a que família pertence? Do Sul de Minas? Ah! Não conheço. Engraçado! Nunca ouvi falar!”

Luís: Isto não é nada, perto da humilhação que pode sofrer aqui, creia.

Leila: Quebrados! Querendo ser nobres à força. Nunca percebeu, não é? Não é de bom gosto perceber-se grosserias, mesmo quando são dirigidas à sua mulher! "Fala francês, Leila? Não?! Joga bridge, Leila? Não?!" Hipócritas! Se quiser, pode ir. Eu fico tomando conta do que é meu.

Luís: Não me obrigue a fazer o que não quero, Leila!

Leila (retesada): Quatrocentos anos! Essa é boa. Isso já está fora da moda, meu caro. Você pode ter quatrocentos anos, mas sou eu quem tem isto! Isto...! ( $F a z o$ gesto do dinheiro, com os dedos). (Andrade, 1970, p.221).

Mas a questão em $O$ telescópio é outra, referente à herança e brigas de família, portanto a discussão entre o casal segue por outro caminho. Percebe-se que o teor do texto de 1961 extrapola a visão representada nesse primeiro texto do autor. Importante é notar, entretanto, o diálogo entre as peças de Jorge Andrade, a unidade de seu pensamento acerca da tradição paulista - que não expressa contradição - e o aprofundamento empreendido no tema, como pode ser visto em primeiro plano na peça Os ossos do barão (1962).

Para entender a composição de Os ossos do barão, faz-se necessário voltar ao Labirinto (1978, p.167):

Era ele, o meu sogro, a nova presença que pressentira no labirinto, com sua expressão bondosa, mas que também podia refletir uma fúria inaudita. Foi por causa dele que pensei em Fernão Dias: ele descende diretamente de Verônica Dias, irmã do grande bandeirante. Com ele entraram na minha vida as dezesseis famílias da caravela de Martin Afonso de Souza e toda a sua descendência de quatro séculos. Minha mulher descende, por parte de pai e mãe, das dezesseis. E seu avô, o senhor França, fazia questão de me repetir isto milhares de vezes. $\mathrm{O}$ avô, não o pai! E fiquei conhecendo, então o verdadeiro orgulho paulista, de gente enraizada na história, de pessoas que entram no Museu do Ipiranga e reconhecem nos retratos e quadros, parentes seus, e, nos móveis e objetos, pertences de família.

Escrita à guisa de comédia, o centro da questão de Os ossos do barão é o casamento de Martino Ghirotto, filho do imigrante italiano Egisto Ghirotto, e Izabel, bisneta do barão que primeiro empregou Egisto, quando este chegou ao Brasil. Pertencente a uma nova classe dominante financeiramente, Egisto comprou todos os antigos pertences do barão e pretende ser enterrado ao seu lado, no jazigo da família.

O cerne do conflito da peça se dá entre as figuras de uma burguesia erudita, mas falida, representada pelos descendentes do barão, e uma nova burguesia, iletrada, da qual fazem parte os italianos Egisto, sua mulher, Bianca, e o filho, Martino. Tal conflito reflete na relação dos jovens com o seu passado familiar: 
Izabel (subitamente): Sabe quem sou eu?

Martino: Izabel.

Izabel: Errou. Eu sou a neta!

Martino: Bem! Todos nós... (para, subitamente, aborrecido).

Izabel: Você ia dizendo que todo mundo descende de alguém. Claro! Mas, eu sou somente neta, bisneta, tataraneta. Cada vez que me apresentam é como se lessem a nobiliarquia paulistana. Você está numa festa e... de repente, se vê cercado por uma infinidade de gente morta. Pra isto basta uma simples apresentação.

Martino: Reaja!

Izabel: Você não sabe o que é carregar uma caravela inteira nas costas!

Martino (sorri): A de Martim Afonso de Sousa? (Andrade, 1970, p.422).

Izabel reverbera a presença da esposa no imaginário andradino, como ele próprio anuncia em Labirinto (1978, p.169):

[Fernão Dias] entrou histórica e genealogicamente falando [na vida do autor], porque minha mulher não vive apregoando tradição. Pelo contrário. Aprendeu com o pai a dar valor à pessoa humana, ao que cada um representa como trabalho, como contribuição ao crescimento do outro. Destituída de qualquer preconceito, com incrível capacidade de humildade e dedicação, ela vê em todos predicados que ninguém vê. Com ela veio um mundo rico de tradições, de história e de humanidade. E foi sua mente, moldada pelo pai, voltada para o presente, mas assumindo o passado, que me ensinou a interpretar minha própria história.

Helena de Almeida Prado é refletida em Izabel, de Os ossos do barão, mas também em Izabel, de $A$ escada, e nas Lavínias de Rasto atrás e $O$ sumidouro, as três últimas esposas todas de uma personagem chamada Vicente, alterego de Jorge Andrade. Sua lucidez e seus pés calcados no presente são demonstrados em várias passagens, como:

Martino: Jogue fora esse orgulho, menina. Ele não ajuda você em nada.

Izabel: Orgulho, por quê?

Martino: Você, como seu pai, sofre só porque vê que o que possuíam está nas mãos de um imigrante, de um ex-colono. Decerto é por isto que chorava.

Izabel: Parece que quem sofre por causa disto é você. Tudo isto não me interessa. (Andrade, 1970, p.431)

A clareza com que encara o passado e o presente familiar faz com que Izabel, no terceiro ato, já esposa de Martino, escolha o nome do filho como Egisto Ghirotto Neto. Esta afronta direta à tradição familiar não passa desapercebida pelos convidados do batizado do menino, seus tios que perderam toda a fortuna do barão:

Clélia: Você comete sempre o mesmo engano, Lucrécia.

Lucrécia: Lourenço, tenho certeza.

Clélia: E insiste! Lourenço não é nome da família. Ainda se fosse Gaspar, Inácio ou Antônio. Em três séculos só puseram uma vez o nome Lourenço.

Lucrécia (teimosa): Lourenço!

Clélia: Você é cabeçuda! Alfredo!

Alfredo: Baltazar!

Clélia: Está vendo? Este é o verdadeiro nome da família. E é lógico, pois a família principiou na capitania em Baltazar de Godoy, cavalheiro castelhano, que por tal sempre foi estimado. Veio para o Brasil no tempo em que os reis de Castela eram também de Portugal.

$[\ldots]$ 
Lucrécia: Como você mora longe, Izabel!

Izabel: A senhora é quem mora longe. E tio Alfredo? Está mais forte?

Alfredo: Vou bem, Izabel Camargo Parente de Rendon Pompeo e Taques!

Lucrécia: Poucos nomes foram tão graciosos!

Izabel (amável): Não conheço nenhuma Izabel com este nome, tio Alfredo.

Lucrécia: Você, minha filha.

Izabel: Eu me chamo Izabel Ghirotto, tia Lucrécia.

(Lucrécia, Clélia e Alfredo trocam um olhar, fingindo que não ouviram)

$[\ldots]$

Verônica: Seu pai não diz nada, Izabel, mas sei que está sentido!

Izabel: Sentido com quê?

Verônica: Afinal, minha filha, é o primeiro neto dele. E é costume da família, há três séculos, por o mesmo nome no filho mais velho!

Izabel: Já quebrei outros tabus da família, quebro este também.

Verônica: Todos chamavam Miguel!

Izabel: Meu filho vai se chamar Egisto. Egisto Ghirotto Neto. (Andrade, 1970, p.439-444)

Os tios Alfredo, Lucrécia e Clélia de Izabel são a representação estereotipada dos quatrocentões com que Jorge Andrade convive e, portanto, aprofunda seu entendimento a partir do casamento com Helena. Inclusive, à maneira labiríntica, o autor retoma diálogos da peça em sua autobiografia - fazendo pressupor que aqueles, por sua vez, retomavam as conversas de sala da família Almeida Prado:

Era uma outra forma de decadência que cruzava meus caminhos, não rural, mas urbana e de uma sociedade já estratificada. Todas as vezes que me lembro não posso deixar de sorrir e, sorrindo, vejo Sérgio [Buarque de Holanda] se servindo novamente de uísque, mas com expressão maliciosa. (Andrade, 1978, p.170)

A evocação à figura de Sérgio Buarque de Holanda, a quem entrevistou para escrita de uma reportagem para a Revista Realidade, não é descrita no Labirinto aleatoriamente - e nem tampouco o é a evocação da família quatrocentona da esposa neste momento da narrativa. Com a ajuda indireta que fornece Sérgio, o narrador de Labirinto descobrirá um caminho para lidar com o passado:

Geralmente, confundem historiador com antiquário, adorador do passado. Escrever história é ter visão dialética do passado e, eventualmente, de suas consequências no presente. É iluminar o passado com o presente, ou vice-versa. É o presente que importa e é através dele que compreendemos a evolução humana. (Andrade, 1978, p.173).

Aprender a lidar com o passado é o tema central em O sumidouro, última peça do ciclo Marta, a árvore e o relógio:

Vicente: Depois de acabar com os demônios familiares, é preciso exterminar os culturais. Aprendi que estão, todos, mexendo o mesmo caldeirão. E lá dentro, quem é cozido, são pessoas como eu. (Andrade, 1970, p.534)

O olhar dialético do passado sempre presente nos textos dramáticos de Jorge Andrade é levado às últimas consequências em $O$ sumidouro, no diálogo estabelecido entre Vicente, personagem do presente e alterego do autor, e Fernão Dias, personagem histórico-mítica que materializa o passado paulista no imaginário andradino: 
De uma delas [das pessoas da família de Helena] cheguei a ouvir, enquanto observava a cama que dizia ter pertencido a Fernão Dias: "Sabe do que me lembrei imediatamente? De vovô deitado nesta belíssima cama - ele não se cansava de dizer que Fernão Dias havia dormido nela também! - e descrevendo a casa de primo Guilherme. Uma casa, onde existiam sempre arrumadas mais de cem camas, todas com cortinado, lençóis guarnecidos de rendas e objetos de prata em todos os quartos! "Prata conquistada por nossos antepassados - dizia ele - no reino do Peru, nas minas de Potosi!" Uma casa onde se podia chegar a qualquer hora do dia ou da noite, que se encontrava sempre um empregado à espera. Entregavam-se os cavalos... e só eram vistos na hora de partir, mas com arreios engraxados e estribos e freios polidos! (Andrade, 1978, p.167). ${ }^{11}$

Jorge Andrade, transfigurado em Vicente em $O$ sumidouro, acerta contas com o passado cultural do povo paulista, trazendo para o primeiro plano da história a personagem José Dias, filho mameluco de Fernão Dias, que apenas existe nos livros de História para apresentar a traição que cometeu contra o pai, ao postergar o seguimento da bandeira:

Vicente (ri): Assim, o Brasil foi criado pela aristocracia colonial à sua imagem e semelhança. No meio de tanta finura sonhada, o povo sumiu como se fosse prova de crime hediondo.

(José Dias destaca-se das árvores e se aproxima, admirando a pedra)

Vicente: Resultado das famigeradas nobiliarquias, onde José Dias, sendo seu filho, não pertence à sua linhagem. Também... a história tem sido escrita pelos ganhadores! Nela, José Dias só existiu no crime. Isto também é matar. Seu filho precisava mesmo desaparecer, era necessário apagar a imagem dele. (Cochicha). É muito perigosa.

Fernão Dias: Perigosa por quê?

Vicente: Você verá. (Aproxima-se de José Dias) A quem amou? Com quem casou? Teve filhos? Ninguém sabe. E para que saber! E apenas um mameluco. Por isto me fascina: é um homem sem rosto... com o rosto de cada um. (Andrade, 1970, p.563)

Jorge Andrade completa o ciclo ao encontrar os séculos XX e XVII nas figuras de Vicente e Fernão Dias e, paralelamente, ao encontrar-se Vicente ao lado de Lavínia, interligando todas as figuras históricas, personagens literárias e pessoas de sua família, construindo seu mundo e sua libertação, virando todos "no mesmo caldeirão". Assim que o conselho de Izabel de $A$ escada:

Izabel: A peça sobre Fernão Dias está parada há um ano. A que pretendia escrever sobre as confrarias de Ouro Preto, ficou apenas na intenção. Em vez de sofrer pelo passado, use-o para se realizar. Ele não está contido no presente de todo mundo? Pegue essa gente, barões ou não, e jogue no palco. É uma boa maneira de se libertar. (Andrade, 1970, p.392)

\section{[...] é atribuído à Lavínia de O sumidouro:}

\footnotetext{
${ }^{11}$ Labirinticamente ainda, a supor a legitimidade da memória de Jorge Andrade, esta passagem de Labirinto é a reprodução quase exata de uma fala de Miguel à esposa, em Os ossos do barão (p.411-412): "(olhando à sua volta) Tenho impressão de estar fazendo uma visita ao passado. (Sorri com carinho) Sabe do que me lembrei imediatamente, Verônica? De vovô deitado nesta belíssima cama - ele não se cansava de dizer que Fernão Dias havia dormido nela também! - e descrevendo a casa de primo Guilherme. Uma casa, onde havia sempre arrumadas mais de cem camas, todas com cortinado, lençóis guarnecidos de rendas e objetos de prata em todos os quartos! 'Prata conquistada por nossos antepassados - dizia ele - no reino do Peru, nas minas de Potosi!' Uma casa onde se podia chegar a qualquer hora do dia ou da noite, que se encontrava sempre um empregado à espera. Entregavam-se os cavalos... e só eram vistos na hora de partir, mas com arreios engraxados e estribos e freios polidos".
} 
Lavínia: Voltou mesmo diferente da viagem a Jaborandi!

Vicente: Não foi a viagem. Foi o trabalho. Já se esqueceu? "Pegue essa gente, barões ou não, e jogue no palco. É uma boa maneira de se libertar". Conselho seu! (Andrade, 1970, p.586)

Assim, não é no plano horizontal que a dramaturgia de Jorge Andrade caminha, no sentido de reler e reaver o passado como material sígnico-imagético de suas peças. Seu caminho é vertical, aprofundando nas idiossincrasias da sua identidade individual, familiar, coletiva e universal, ultrapassando a reprodução autobiográfica e tornando memória e história significativas no campo da sua produção artística, tabuleiro em que verdade e ficção se retroalimentam.

Vicente: Sou grato a Fernão Dias: você é minha mulher. Só espero que não precise vender suas coisas.

Lavínia: Não estamos muito longe, não. (Riem) E eu? Devo agradecer você, a quem?

Vicente: Gostaria que fosse a José Dias. Não sou, como ele, um homem sem rosto, com o rosto de cada um? Não vivo dividido em mil pedaços? (Andrade, 1970, p.586)

O sumidouro, última peça na estrutura do ciclo e última peça a ser cronologicamente escrita, traz em si a consciência de fechamento do escritor:

Vicente (perdido): Em 29 minha avó tirou o relógio da fazenda. Presenciei tudo! Foi quando comecei a procurar a toda parte... e em mim mesmo. Aí, nasceu o sentimento de mundo perdido, agora reencontrado. (Andrade, 1970, p.586-587)

Esta consciência é descrita na resposta à pergunta de Mariângela Alves de Lima, em 1976 (TR-1823, CCSP, p.4):

M.A.: Lendo o ciclo, a impressão que eu tenho é que ela começa como uma história pessoal, dessa história pessoal você vai percebendo as relações com o país e daí você, conscientemente, tenta fazer a História do país.

J.A.: Exato. Quer dizer, ela começa como uma história imediata, uma memória próxima, familiar, da família, e essa memória vai se alargando na medida em que ele vai tendo uma visão de como... como é que eu posso dizer?... Como era incluída esta família num contexto cada vez maior. Ela foi se alargando. Até, por exemplo, você percebe no ciclo "Marta, a árvore, o relógio", depois que eu reuni as dez peças e que eu vi claramente que as dez peças contavam todo o ciclo da família paulista, que vai de Fernão Dias até o intelectual, em 1970, fica claro... é como se eu não tivesse escrito uma única peça. Eu escrevi uma peça que se chama "Marta, a árvore, o relógio", que em vez de ter três atos tem dez peças.

Neste texto, menos do que buscar todos os levantamentos memorialísticos, históricos e culturais que permearam a escrita andradina, buscou-se entender um dos braços de sua dramaturgia - o uso da memória e da vida pessoal como fonte de imaginário poético para construção dos textos - e, mais especificamente, uma pequena porção deste recurso - a influência do contato e ingresso na família da esposa, uma tradicional família quatrocentona - como recurso poético autoficcional de composição do ciclo Marta, a árvore e o relógio. 


\section{Referências}

ANDRADE, Jorge. Transcrição do depoimento à Semana do Escritor Brasileiro. Arquivo Municipal Multimeios, Centro Cultural São Paulo, fundo Jorge Andrade. Doc TR 0345, 1979.

ANDRADE, Jorge. Labirinto. Rio de Janeiro: Paz e Terra, 1978.

ANDRADE, Jorge. Transcrição de entrevista concedida ao Centro de Documentação e Informação sobre Arte Brasileira Contemporânea. Entrevistadores: Mariângela Alves de Lima, Linneu Dias, Carlos Eugênio Marcondes de Moura. Arquivo Municipal Multimeios, Centro Cultural São Paulo, fundo Jorge Andrade. Doc TR 1823.São Paulo, 22 de outubro de 1976.

ANDRADE, Jorge. Marta, a árvore e o relógio. São Paulo: Perspectiva, 1970.

ANDRADE, Jorge. O telescópio. In: Marta, a árvore e o relógio. São Paulo: Perspectiva, 1970, p.189-228.

ANDRADE, Jorge. A escada. In: Marta, a árvore e o relógio. São Paulo: Perspectiva, 1970, p.339-394.

ANDRADE, Jorge. Os ossos do barão. In: Marta, a árvore e o relógio. São Paulo: Perspectiva, 1970, p.395-454.

ANDRADE, Jorge. O sumidouro. In: Marta, a árvore e o relógio. São Paulo: Perspectiva, 1970, p.527-558.

ANDRADE, Jorge. Entrevista. Arquivo Municipal Multimeios, Centro Cultural São Paulo, fundo Jorge Andrade. Doc. DT 7704, s/d.

BAKHTIN, Mikhail. Teoria do romance II: as formas do tempo e do cronotopo. Trad. Paulo Bezerra. São Paulo: Editora 34, 2018.

CANDIDO, Antonio. Ficção e confissão. Rio de Janeiro: Ouro sobre Azul, 2006.

DOUBROVSKY, Serge. Fils [1977]. Paris: Gallimard, 2001.

FARACO, Carlos Alberto. Autor e autoria. In: BRAIT, Beth (org.) Bakhtin: conceitos-chave. 5.ed. São Paulo: Contexto, 2017.

FRANKEL, Roy David. Quando não utilizar dados biográficos na análise literária: uma discussão baseada na analítica existencial de Martin Heidegger e no romance O Lobo da Estepe de Hermann Hesse. Criação e Crítica, n. 12, jun. 2014, p.53-65. 
KLINGER, Diana. Escritas de si, escritas do outro: o retorno do autor e a virada etnográfica. Rio de Janeiro: 7Letras, 2007.

LEITÃO, Cláudio. Posfácio. In: RAMOS, Graciliano. Infância. 48. ed. Rio de Janeiro: Record, 2015. p. 269-282.

LEJEUNE, Philippe. O pacto autobiográfico (1973). Trad. Jovita Maria Gerheim Noronha e Maria Inês Coimbra Guedes. Belo Horizonte: Editora UFMG, 2014.

LIMA, Bruno. Eu: itinerário para a autoficção. Rio de Janeiro: 7letras, 2015.

MAGALDI, Sábato. Prefácio. In: ANDRADE, Jorge. Labirinto. Rio de Janeiro: Paz e Terra, 1978.

MITIDIERI, André Luís. Da produtividade dialógica no espaço biográfico. Bakhtiniana, v. 8, n. 1, jan./jun. 2013, p.140-156.

MORSE, Richard. Mito urbano e realidade. In: ANDRADE, Jorge. Marta, a árvore e o relógio. São Paulo: Perspectiva, 1970, p.645-648.

NORONHA, Jovita Maria Gerheim (org.). Ensaios sobre a autoficção. Trad. Jovita Maria Gerheim Noronha e Maria Inês Coimbra Guedes. Belo Horizonte: Editora UFMG, 2014.

RAMOS, Graciliano. Infância (memórias) (1945). São Paulo/Rio de Janeiro: Record, 2015.

RAMOS, Graciliano. Vidas secas (1938). São Paulo/Rio de Janeiro: Record, 2016.

SANT'ANNA, A. R. Vidas Secas. In: Análise estrutural de romances brasileiros. Petrópolis: Editora Vozes, 1989.

SOBRAL, João Jonas Veiga. Português: vestibular + enem. São Paulo: Abril, 2016.

TARIFEÑO, Leonardo. 27\% de verdad. Tierra Adentro, v. 222, may/jun 2017, p.44-51.

Recebido em: 29/01/2019

Aprovado em: 21/05/2019 